\title{
Effect of emamectin benzoate on the molt cycle of ovigerous American lobsters Homarus americanus is influenced by the dosing regimen
}

\author{
S. L. Waddy*, V. A. Merritt, M. N. Hamilton-Gibson, D. E. Aiken \\ Fisheries and Oceans Canada, Biological Station, 531 Brandy Cove Road, St. Andrews, New Brunswick E5B 2L9, Canada
}

\begin{abstract}
Emamectin benzoate, the active ingredient in SLICE ${ }^{\circledR}$, targets the nervous system of arthropods. Ingestion of high doses causes ovigerous American lobsters Homarus americanus to molt before their eggs hatch. To determine the effect of repeated exposure to doses at or below the noobserved-effect level (NOEL) of a single exposure (NOEL: $0.12 \mu \mathrm{g} \mathrm{g}^{-1}$ ), ovigerous lobsters were given either a single dose of $0.5 \mathrm{\mu g} \mathrm{g}^{-1}$ or a succession of lower doses at $14 \mathrm{~d}$ intervals that provided similar cumulative exposures $\left(0.06 \mu \mathrm{g} \mathrm{g}^{-1} \times 8,0.125 \mu \mathrm{g} \mathrm{g}^{-1} \times 4\right.$, or $\left.0.25 \mathrm{\mu g} \mathrm{g}^{-1} \times 2\right)$. The study was conducted between July 2003 and September 2004. Groups repeatedly administered doses of 0.06 and $0.125 \mu \mathrm{g}$ $\mathrm{g}^{-1}$ had higher rates of premolt induction (87 and $89 \%$, respectively) than groups given 1 or 2 higher doses $(35 \%)$. Lobsters in the 8 - and 4 -dose groups had difficulty molting, and a significant proportion died at molt stages $\mathrm{D}_{3}$ to $\mathrm{B}$ ( 35 and $30 \%$, respectively, versus 0 and $5 \%$ in the 1- and 2-dose groups). The results demonstrate that repeated exposure to emamectin benzoate (1) produces effects not seen when an equivalent quantity of the drug is administered in 1 or 2 doses, and (2) causes a dose less than the single-dose NOEL to become a very potent dose. However, the potential risk of emamectin benzoate to lobsters foraging near salmon farms cannot be determined from these results because the cumulative dose is greater than lobsters are likely to acquire. Further work is needed using lower, more realistic doses.
\end{abstract}

KEY WORDS: Emamectin benzoate - American lobster - Homarus - Repeated exposure • Premature molt Resale or republication not permitted without written consent of the publisher

\section{INTRODUCTION}

Emamectin benzoate, the active ingredient in SLICE ${ }^{\circledR}$ (a commercial feed pre-mix), is an effective and widely-prescribed drug administered in fish feed to control sea lice (Lepeophtheirus salmonis and Caligus spp.) on farmed salmon (primarily Salmo salar; SPAH 2002). The drug is an avermectin derivative that inhibits neurotransmission in the peripheral nervous system of arthropods (Mellin et al. 1983, McKellar \& Benachaoui 1996). Secondary effects on growth, development, and reproduction have been reported in insects (Glancey et al. 1982, Antunes et al. 2005). Ovigerous American lobsters Homarus americanus that ingest high doses of emamectin benzoate enter premolt (molt stage $\mathrm{D}_{1}$; setogenic stage 3.0 ) prema- turely and lose their attached eggs with the cast shell (Waddy et al. 2002, 2007a).

Residues of emamectin benzoate have been found in crabs (Pagurus spp. and Carcinus maenas) collected near Scottish salmon farms shortly after SLICE was used to control sea lice infestations (Telfer et al. 2006). American lobsters are reported to aggregate near aquaculture sites and eat waste salmon feed (Iwama 1991, Findlay et al. 1995, Hargrave 2003, Walters 2007). In a laboratory study, ovigerous lobsters were initially attracted to SLICE-medicated feed, but rapidly began feeding selectively on their natural diet (Waddy et al. 2007b). The estimated dose ingested in $14 \mathrm{~d}\left(0.021 \mathrm{\mu g} \mathrm{g}^{-1}\right.$ body weight) was less than the noobserved-effect level (NOEL: $0.12 \mu \mathrm{g} \mathrm{g}^{-1}$ ) of a single dose (Waddy et al. 2007a,b). 
The effects of neurotoxins can accumulate with repeated exposure (Greim \& Snyder 2008) and there are indications this may occur in arthropods exposed to avermectins. The lethal concentration of ivermectin to the tsetse fly Glossina morsitans, for example, is significantly lower when the chemical is administered in repeated blood meals than in a single meal (Langley \& Roe 1984). In the German cockroach Blatella germanica, there appears to be an inverse relationship between the dose required to cause an effect and the length of exposure (Cochran 1985).

This raises the possibility that the effect of emamectin benzoate on ovigerous American lobsters could be influenced by the dosing regimen. In this paper, we compared the response of ovigerous lobsters repeatedly exposed to doses of the drug at or below the NOEL of a single dose, to that of lobsters given 1 or 2 doses above the lowest-observed-effect level (LOEL: $0.22 \mu \mathrm{g} \mathrm{g}^{-1}$ ).

\section{MATERIALS AND METHODS}

Lobsters and holding conditions. Mature female lobsters (mean weight $\pm \mathrm{SD}=557 \pm 95 \mathrm{~g}$ ) that recently molted (stages $\mathrm{C}_{1}$ to $\mathrm{C}_{3}$ ) were purchased from the commercial catch at Miminegash, Prince Edward Island (southern Gulf of St. Lawrence), Canada, in September 2002. From the time of capture, and during the study, the lobsters were held communally with excess shelter in fiberglass tanks $(1.8 \times 2.4 \times 0.5 \mathrm{~m}$ deep $)$ at a density of 10 lobsters $\mathrm{m}^{-2}$. The tanks were located in a greenhouse, which provided natural seasonally-changing day lengths (latitude $45^{\circ} \mathrm{N}$ ). Filtered, unheated seawater was provided to each tank at a rate of $101 \mathrm{~min}^{-1}$. Water temperature varied seasonally from $0^{\circ}$ to $14^{\circ} \mathrm{C}$, with the maximum occurring in September.

The study began on 24 July 2003, when the seawater was $12^{\circ} \mathrm{C}$. The lobsters had spawned within the previous
$4 \mathrm{wk}$, and were in a prolonged intermolt (molt stages $\mathrm{C}_{4}$ to early $\mathrm{D}_{0}$ ). They were not expected to molt until late in the summer of 2004, after the eggs hatched (see Waddy \& Aiken 2005 for a description of the biennial molt and reproductive cycle). Each animal was identified using Brother ${ }^{\circledR}$ P-touch TZ tape attached to Panduit ${ }^{\circledR}$ marker ties (PAN-PLM2S-D) fastened around each cheliped. The lobsters were fed to satiation, except on the day before and the day of each exposure, on fresh and freshfrozen shrimp, mussels, clams, squid, and fish.

Experimental design and drug exposure. Emamectin benzoate was orally administered in slurries prepared from $3.5 \mathrm{~mm}$ commercial salmon pellets. The pellets were processed with seawater $\left(2 \mathrm{ml} \mathrm{g}^{-1}\right)$ to a smooth consistency in a small food processor. Emamectin benzoate (Merck, technical grade) was dissolved in $2 \mathrm{ml}$ of propylene glycol and added to 4 slurries in amounts that enabled doses of $0.50,0.25,0.125$, and $0.06 \mu \mathrm{g} \mathrm{g}^{-1}$ to be administered in $1 \mathrm{ml}$ or less of slurry. Fresh slurries were prepared on each treatment day.

Lobsters were force-fed using $1 \mathrm{ml}$ disposable plastic syringe barrels. The control lobsters $(n=19)$ were given a dose of unmedicated slurry on Day 1 that contained a similar amount of propylene glycol as the medicated slurries. The single-dose group $(n=25)$ was given a nominal dose of $0.5 \mathrm{\mu g} \mathrm{g}^{-1}$ on Day 1, while the 20 lobsters in each of the other groups received smaller doses on Day 1 and at $14 \mathrm{~d}$ intervals $\left(0.25 \mu \mathrm{g} \mathrm{g}^{-1} \times 2,0.125 \mu \mathrm{g} \mathrm{g}^{-1} \times 4\right.$, and $0.06 \mu \mathrm{g} \mathrm{g}^{-1} \times 8$ ). Three lobsters in the $0.06 \mu \mathrm{g} \mathrm{g}^{-1} \times$ 8 group received only 6 or 7 doses because they were about to molt (setogenic stage 5.5 , molt stage $\mathrm{D}_{3}$ ) by the time the 7 th and 8th exposures were administered. These lobsters are included in the data analysis.

Two $5 \mathrm{~g}$ samples from each of the 16 slurries used in the study were frozen for analysis. The measured quantity of emamectin benzoate (Table 1) was determined by ETL/Xenos Laboratories (Nepean, Ontario, Canada) using high-performance liquid chromatography (see Burridge et al. 2004 for methodology).

Table 1. Homarus americanus. Effect of dosing regimen on mean time to molt (stage E) and molt success in ovigerous American lobsters orally administered a cumulative nominal dose of $0.5 \mathrm{\mu g} \mathrm{g}^{-1}$ emamectin benzoate in either a single dose or a succession of smaller doses at $14 \mathrm{~d}$ intervals. MII: Molt Impact Index (see Table 2). ${ }^{*}$ Significantly different from the control group ( $p<0.05$; Kruskal-Wallis analysis of variance, ANOVA, on ranks and Dunn's test). ${ }^{* *}$ Significantly different from the control, $0.5 \mu \mathrm{g} \mathrm{g}^{-1} \times 1$, and $0.25 \mu \mathrm{g} \mathrm{g}^{-1} \times 2$ groups ( $\mathrm{p}<0.05$; Kruskal-Wallis ANOVA on ranks and Dunn's test)

\begin{tabular}{|lccccc|}
\hline $\begin{array}{l}\text { Nominal dosing } \\
\text { regimen }\left(\mu \mathrm{g} \mathrm{g}^{-1} \times\right. \\
\text { number of doses })\end{array}$ & $\begin{array}{c}\text { Cumulative } \\
\text { measured dose } \\
\left(\mu \mathrm{g} \mathrm{g}^{-1}\right)^{\mathrm{a}}\end{array}$ & $\mathrm{n}$ & \multicolumn{2}{c|}{$\begin{array}{c}\text { Mean time of molt } \\
\text { Days } \pm \text { SD }\end{array}$} & $\begin{array}{c}\text { Date } \\
\text { molt success } \\
(\mathrm{MII} \pm \mathrm{SD})\end{array}$ \\
\hline Control $(0 \times 1)$ & 0.001 & 19 & $412 \pm 6$ & 9 Sep 2004 & 0 \\
$0.5 \times 1$ & 0.39 & 25 & $281 \pm 166^{*}$ & 1 May 2004 & $0.1 \pm 0.5$ \\
$0.25 \times 2$ & 0.48 & 20 & $311 \pm 146^{*}$ & 31 May 2004 & $0.1 \pm 0.5$ \\
$0.125 \times 4$ & 0.47 & 20 & $127 \pm 110^{*}$ & 28 Nov 2003 & $2.0 \pm 2.1^{* *}$ \\
$0.06 \times 8$ & 0.45 & 20 & $151 \pm 105^{*}$ & 22 Dec 2003 & $2.4 \pm 2.3^{* *}$ \\
a Determined by ETL/Xenos Laboratories & & & & \\
\hline
\end{tabular}


Progression through the molt cycle was monitored in each lobster by periodically assessing the degree of setal development in the pleopods (see Aiken 1973, 1980 for methods of determining molt and setogenic stages). Up to 14 successive samples were taken from each lobster to determine when they entered premolt (transition from setogenic stage 2.5 to 3.0 , molt stage $\mathrm{D}_{0}$ to $\mathrm{D}_{1}$ ).

Endpoints used to assess the effect of the drug were (1) premature onset of premolt (defined as reaching setogenic stage 3.0 within 5 mo of first exposure to the drug), (2) mean time to molt, (3) Molt Impact Index (MII), which quantified the effect of the drug on molt success and recovery (Table 2), (4) survival, and (5) molt-related mortality.

Statistics. XLStat 2008 software (Kovach Computing) was used to analyze the data. The proportions of lobsters that survived, entered premolt prematurely, and died at molt were compared using the chi-squared test for equality of more than 2 proportions. If the null hypothesis of equal proportions was rejected by the chi-squared test, then the Marascuillo procedure was used to identify which group proportions differed.

Mean time to molt and Molt Impact Index were compared using 1-way ANOVA or Kruskal-Wallis ANOVA on ranks. When a difference was found, the treatment groups were compared using Dunn's test. Differences were considered statistically significant when $\alpha<0.05$.

\section{RESULTS}

\section{Premolt induction and time of molt}

Mean time to molt differed among the groups (Kruskal-Wallis $H=38.911$, df $=4$, p < 0.001). Molting occurred significantly sooner in the drug-treated groups (Dunn's test $Q=3.455$ to 5.625 , $\mathrm{p}<0.05$ ) than in the control group (Table 1).
There were also differences in the proportions of the groups that entered premolt prematurely $\left(\chi^{2}=41.1\right.$, $\mathrm{df}=4, \mathrm{p}<0.0001$ ). The 4 - and 8 -dose groups had a significantly higher incidence of premature onset of premolt (87 and $89 \%$, respectively) than the control $(0 \%)$ and 1- and 2-dose groups (35\%, Marascuillo procedure; Fig. 1A).

\section{Survival and impact on molt success}

Survival differed among the groups $\left(\chi^{2}=19.9\right.$, df $=4$, $\mathrm{p}<0.001)$. Survival in the 4 - and 8-dose groups $(45 \%)$ was significantly lower than in the control (100\%) and 1 - and 2-dose groups (76 and 75\%, respectively, Marascuillo procedure; Fig. 1B).

Control lobsters had no difficulty molting (mean MII =0), and MII in the 1- and 2-dose groups were not significantly different from the control group $(Q=$ 0.444 and 0.292 , respectively; $p>0.05$ ); (Table 1 ). The 4- and 8-dose groups had MII that were significantly higher $(Q=2.690$ and 2.903 , respectively, $\mathrm{p}<0.05)$ than the control and 1- and 2-dose groups.

There were also differences among the groups in the proportion of lobsters that died at or near molt (stages $\mathrm{D}_{3}$ to $\mathrm{B}_{i} \chi^{2}=23.7$, df $=4, \mathrm{p}<0.01$ ). Molt-related mortality was significantly greater in the 4- and 8-dose groups (30 and 35\%, respectively) than in the control $(0 \%)$ and 1 - and 2-dose groups (0 and 5\%, respectively, Marascuillo procedure; Fig. 1C). Some lobsters died soon after the first or second exposure to the drug, when they were still in intermolt (setogenic stages $\leq 2.5 ; 20,15,20$, and $5 \%$, in the 1 - to 4 -dose groups, respectively); there was also mortality during early to mid-premolt (setogenic stages 3.0 to $5.0 ; 4,5,5$, and $15 \%$, respectively). However, the differences in mortality among the groups were not significant (intermolt: $\chi^{2}=12.0,9 \mathrm{df}, \mathrm{p}=0.24$; early to mid-premolt: $\chi^{2}=$ $4.0,3 \mathrm{df}, \mathrm{p}=0.26)$.

Table 2. Homarus americanus. Molt Impact Index (MII) for quantifying the effect of emamectin benzoate on molt success and recovery in ovigerous American lobsters. After ecdysis (molt stage E), each lobster was monitored for 200 Celsius degree-days $\left({ }^{\circ} \mathrm{d}_{i}\right.$ cumulative product of time and temperature, e.g. $20 \mathrm{~d}$ at $10^{\circ} \mathrm{C}=200^{\circ} \mathrm{d}$ ) to assess recovery

\begin{tabular}{|c|c|c|}
\hline & MII & Description \\
\hline 0 & Unaffected & $\begin{array}{l}\text { Molted successfully } \\
\text { No indication of neurological disruption (e.g. disorientation, } \\
\text { disturbed water balance, or paralysis of periopods) }\end{array}$ \\
\hline 1 & Slightly affected & $\begin{array}{l}\text { Displayed transitory neurological problems after molting; } \\
\text { recovered within } 200^{\circ} \mathrm{d}\end{array}$ \\
\hline 2 & Moderately affected & $\begin{array}{l}\text { Displayed persistent neurological problems; did not recover } \\
\text { within } 200^{\circ} \mathrm{d}\end{array}$ \\
\hline 3 & Completed ecdysis and began to recover, but then died & Died between 25 and $200^{\circ} \mathrm{d}$ \\
\hline 4 & Completed ecdysis, but died in molt stage A & Died within $25^{\circ} \mathrm{d}$ \\
\hline 5 & Died during ecdysis & Death occurred late in molt stage $\mathrm{D}_{3}$ or in stage $\mathrm{E}$ \\
\hline
\end{tabular}



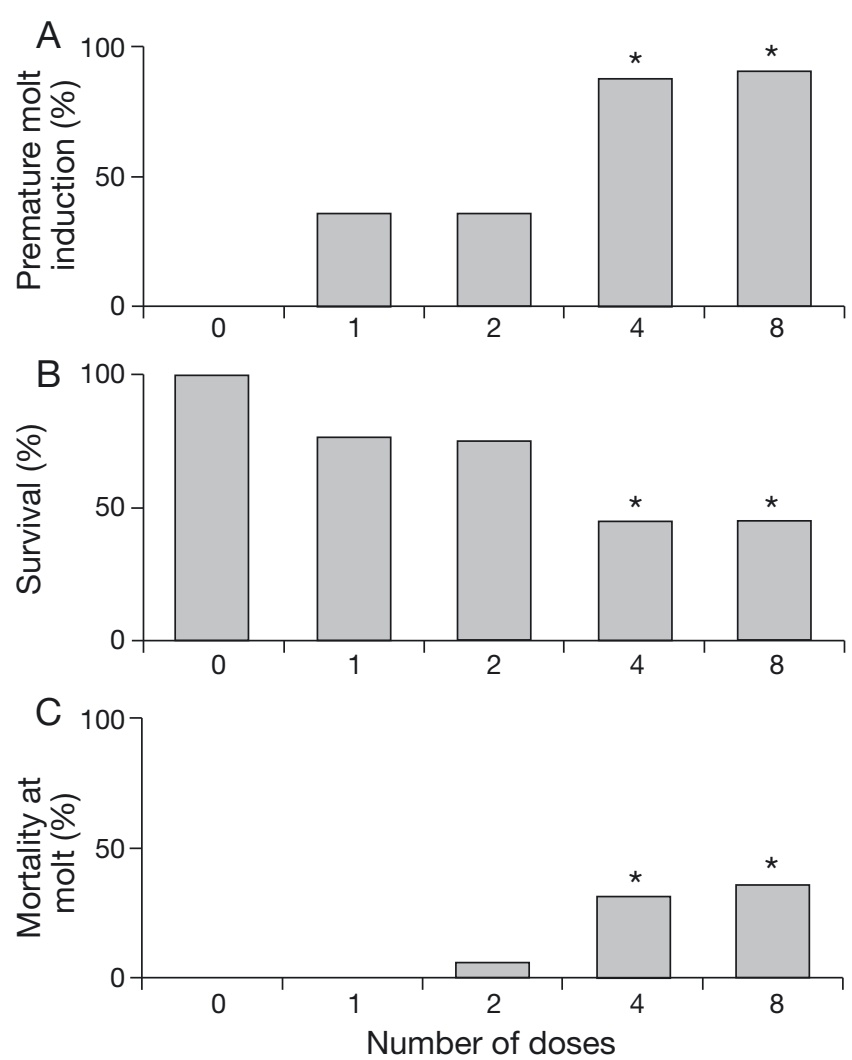

Fig. 1. Homarus americanus. Effect of dosing regimen on the response of ovigerous American lobsters orally administered a cumulative dose of $0.5 \mu \mathrm{g} \mathrm{g}^{-1}$ emamectin benzoate in either a single dose or a succession of 2,4 , or 8 smaller doses at $14 \mathrm{~d}$ intervals that provided the same cumulative dose. (A) Premature onset of premolt, defined as reaching setogenic stage 3.0 (molt stage $\mathrm{D}_{1}$ ) within 5 mo of first exposure to the drug; (B) survival; and (C) molt-related mortality (deaths occurring between molt stage $\mathrm{D}_{3}$ and $\mathrm{B}$ ). ${ }^{*}$ Groups that are significantly different from the control and 1- and 2-dose groups (chi-squared test for equality of more than 2 proportions and Marascuillo procedure)

\section{DISCUSSION}

Ovigerous American lobsters administered 4 or 8 doses of emamectin benzoate over a 6 or $14 \mathrm{wk}$ period had a greater incidence of premature onset of premolt, reduced molting success, and higher mortality, than lobsters given 1 or 2 doses equivalent to the cumulative repetitive doses. Through repeated exposure, a dose of $0.06 \mathrm{\mu g} \mathrm{g}^{-1}$ (half the NOEL of a single dose) became a very potent dose, causing $89 \%$ of the lobsters to enter premolt prematurely and $35 \%$ to die during or shortly after they molted.

The negative effect of repetitive exposure to emamectin benzoate on molt success was unexpected. To quantify the effect of the drug on molt success and recovery, a Molt Impact Index (MII) was developed that allowed both subtle and severe effects to be qual- ified (Table 2). Although a few lobsters in the 1- and 2dose groups displayed minor problems during the molting process, molt success was not significantly different from that of the control group. The 4- and 8-dose groups, in contrast, had higher MII than the other groups (Table 1) and greater mortality in molt stages $\mathrm{D}_{3}$ to $\mathrm{B}$ (Fig. 1C). Mortality related to molt is uncommon in ovigerous lobsters exposed only once or twice to emamectin benzoate (Fig. 1C and Waddy et al. 2007a), but reduced molting success has been reported in insects and copepods exposed to avermectins (Strong \& Brown 1987, Willis \& Ling 2003).

The response of ovigerous American lobsters to repeated emamectin benzoate exposure demonstrates the challenge of determining the NOEL of this drug (cf. Waddy et al. 2007a). As noted in a review by Greim \& Snyder (2008), the NOEL can only be determined for chemicals that produce reversible effects. When the damage caused by a chemical is not repaired, effects can accumulate with repeated exposure. This appears to be the case with emamectin benzoate, as repeated exposure causes effects not seen when lobsters are administered the equivalent quantity of the drug in 1 or 2 doses.

The mechanism involved in the response of American lobsters to emamectin benzoate is unknown, but avermectins potentiate the ability of arthropod neurotransmitters, such as glutamate and $\gamma$-amino butyric acid (GABA), to stimulate the influx of chloride ions into nerve cells. This causes a loss of cell function and disrupts nerve impulses (Mellin et al. 1983, Jansson \& Dybas 1998). This class of chemicals binds to multiple sites in the nervous system and causes diverse effects among arthropods exposed to sublethal doses. Both reversible and irreversible effects can occur, and the type of response can vary with both the dose and nature of the exposure, making it difficult to predict effects (Zufall et al. 1989, Jansson \& Dybas 1998, Turner \& Schaeffer 1998).

Although most of the reported effects of avermectins on arthropods are on the peripheral nervous system, several authors have suggested that the secondary effects on insect growth, development, and reproduction are due to effects on the neurosecretory cells (Glancey et al. 1982, De Azambuja et al. 1985, Antunes et al. 2005). In the American lobster, we hypothesized that emamectin benzoate interferes with the neuroendocrine control of the molting glands (Y organs; Waddy et al. 2002). The primary regulator of molting in crustaceans is thought to be the molt-inhibiting neuropeptide $(\mathrm{MIH})$. An interruption in the synthesis or release of MIH can allow the molting glands to secrete ecdysteroids and the animal to enter premolt. Several lines of investigation support this hypothesis: avermectins modulate the binding of GABA site ligands to insect 
central nervous system membranes (Hawkinson \& Casida 1993); emamectin benzoate can act as a GABA agonist (SPAH 2002); and GABA inhibits release of eyestalk neuropeptides in crustaceans (Sarojini et al. 2000).

The risk from emamectin benzoate exposure is proportional to the quantity of SLICE-medicated salmon feed ingested. Lobsters can be exposed to the drug when salmon farmers use SLICE to control sea lice infestations. Laboratory feeding studies suggest it is unlikely that ovigerous lobsters scavenging near salmon farms would ingest sufficient emamectin benzoate to cause the effects seen in this study (Waddy et al. 2007b and unpublished), especially since the drug does not bioconcentrate in animals or biomagnify in the food chain (Chukwudebe et al. 1996, Telfer et al. 2006). In a 14 d feeding study, ovigerous lobsters offered SLICE-medicated salmon pellets rapidly began rejecting the pellets in favor of invertebrates and other foods (Waddy et al. 2007b). They ingested doses of $\sim 0.015$ and $0.006 \mu \mathrm{g} \mathrm{g}^{-1}$ in the first and second weeks, suggesting that if salmon farmers use the drug for 20 to $50 \mathrm{~d}$ a year, the cumulative dose acquired might be closer to $0.05 \mu \mathrm{g} \mathrm{g}^{-1}$ than the $0.5 \mu \mathrm{g} \mathrm{g}^{-1}$ used in our study.

A relatively high cumulative dose was selected for the current work because we wanted to ensure that the single-dose exposure would have a significant effect on the molt cycle. However, before conclusions can be drawn about the impact of repetitive exposure on molting and egg loss in ovigerous lobsters, further work is needed using more realistic individual (i.e. 0.005 to $0.01 \mu \mathrm{g} \mathrm{g}^{-1}$ ) and cumulative (i.e. 0.05 to $0.1 \mu \mathrm{g} \mathrm{g}^{-1}$ ) doses, as extrapolation from the high doses used in this study may not apply to lower levels. Complicating the design of studies, however, is that it is difficult to speculate how often ovigerous lobsters might encounter medicated feed because they are extremely mobile, and frequency of drug use by salmon farmers varies among farms and between years.

The objective of our study was to determine the response of ovigerous American lobsters to repetitive emamectin benzoate exposure. A factor not tested was whether time of exposure influenced the results, which can be a factor in the response of animals to repetitive doses of insecticides (e.g. Boone \& Bridges 2003). Lobsters were exposed to the drug every $14 \mathrm{~d}$ between late July and early September in the 4-dose group and between late July and late October in the 8-dose group. In previous work, the molting response of ovigerous lobsters to single doses of emamectin benzoate administered in July and October was similar (Waddy et al. 2002), suggesting that timing of exposure was not a significant factor in the influence of repeated exposure in this study.
The results do demonstrate the challenge of projecting responses from single-dose studies to the potential effects of repeated exposure. They also suggest that there is less potential for emamectin benzoate to have adverse effects on lobsters if the drug is ingested over a short period of time than if smaller amounts are acquired over several weeks or months. With current knowledge, however, it is difficult to predict how ovigerous lobsters will respond to exposure regimens other than the ones used in this study.

Acknowledgements. We thank L. E. Burridge for assistance with the preparation of the medicated slurries.

Copyright notice. OHer Majesty in Right of Canada as Represented by the Minister of Fisheries and Oceans.

\section{LITERATURE CITED}

Aiken DE (1973) Proecdysis, setal development and molt prediction in the American lobster (Homarus americanus). J Fish Res Board Can 30:1337-1344

Aiken DE (1980) Molting and growth. In: Cobb S, Phillips BF (eds) The biology and management of lobsters, Vol 1. Physiology and behavior. Academic Press, New York, NY, p 91-163

Antunes EC, Della Lucia TMC, Guedes RNC, Serrão JE (2005) Abamectin-driven alterations on queen ovaries of the leafcutting ant Acromyrmex subterraneus subterraneus (Hymenoptera: Formicidae). Sociobiology 45:163-172

Boone MD, Bridges CM (2003) Effects of carbaryl on green frog (Rana clamitans) tadpoles: timing of exposure versus multiple exposures. Environ Toxicol Chem 22:2695-2702

> Burridge LE, Hamilton N, Waddy SL, Haya K and others (2004) Acute toxicity of emamectin benzoate (SLICETM) in fish feed to American lobster, Homarus americanus. Aquacult Res 35:713-722

Chukwudebe AC, Andrews N, Drottar K, Swiger J, Wislocki PG (1996) Bioaccumulation potential of 4"-epi-methylamino-4"-deoxyaverecin $\mathrm{B}_{1 \mathrm{a}}$ (emamectin benzoate) in bluegill sunfish. J Agric Food Chem 44:2894-2899

Cochran DG (1985) Mortality and reproductive effects of avermectin $\mathrm{B}_{1}$ fed to German cockroaches. Entomol Exp Appl 37:83-88

> De Azambuja P, Lima Gomes JEP, Lopes F, Garcia ES (1985) Efficacy of ivermectin against the bloodsucking insect, Rhodnius prolixus (Hempitera, Triatominae). Mem Inst Oswaldo Cruz 80:439-442

> Findlay RH, Watling L, Meyer LM (1995) Environmental impact of salmon net-pen culture on marine benthic communities in Maine: a case study. Estuaries 18:145-179

Glancey BM, Lofgren CS, Williams DF (1982) Avermectin $\mathrm{B}_{1 \mathrm{a}}$ : effects on the ovaries of red imported fire ant queens (Hymenoptera: Formicidae). J Med Entomol 19:743-747

Greim H, Snyder R (2008) Introduction to the discipline of toxicology. In: Greim H, Snyder R (eds) Toxicology and risk assessment: a comprehensive introduction. John Wiley \& Sons, New York, NY, p 1-18

Hargrave BT (2003) Far field environmental effects of marine finfish aquaculture. Can Tech Rep Fish Aquat Sci 2450: $1-49$

Hawkinson JE, Casida JE (1993) Insecticide binding sites on $\gamma$-aminobutyric acid receptors of insects and mammals. In: Duke SO, Menn JJ, Plimmer JR (eds) Pest control with 
enhanced environmental safety. Amer Chem Soc Symp Ser 524:126-143

Iwama GK (1991) Interaction between aquaculture and the environment. CRC Crit Rev Environ Control 21:177-216

Jansson RK, Dybas RA (1998) Avermectins: biochemical mode of action, biological activity and agricultural importance. In: Ishaaya I, Degleehe D (eds) Insecticides with novel modes of action. Springer-Verlag, New York, NY, p 152-170

Langley RA, Roe JM (1984) Ivermectin as a possible control agent for the tsetse fly, Glossina morsitans. Entomol Exp Appl 36:137-143

McKellar QA, Benachaoui HA (1996) Avermectins and milbemycins. J Vet Pharmacol Ther 19:331-351

Mellin TN, Busch RD, Wang CC (1983) Postsynaptic inhibition of invertebrate neuromuscular transmission by avermectin $B_{1 a}$. Neuropharmacology 22:89-96

Sarojini R, Nagabhushanam R, Fingerman M (2000) New technology for enhancing reproductive maturation in economically important crustaceans for aquaculture. In: Fingerman M, Nagabhushanam R (eds) Recent advances in marine technology, Vol 4. Science Publishers Inc, Enfield, NH, p 177-194

SPAH (Schering Plough Animal Health Corporation) (2002) SLICE technical monograph. Available at www. spaquaculture.com/assets/Slicetec.pdf

Strong L, Brown TA (1987) Avermectins in insect control and biology: a review. Bull Entomol Res 77:357-389

Telfer TC, Baird DJ, McHenery JG, Stone J, Sutherland I, Wislocki P (2006) Environmental effects of the anti-sea lice (Copepoda: Caligidae) therapeutant emamectin benzoate

Editorial responsibility: Judith Grassle, New Brunswick, New Jersey, USA under commercial use conditions in the marine environment. Aquaculture 260:163-180

Turner MJ, Schaeffer JM (1998) Mode of action of ivermectin. In: Ishaaya I, Degleehe D (eds) Insecticides with novel modes of action. Springer-Verlag, New York, NY, p 73-88

- Waddy SL, Aiken DE (2005) Impact of invalid biological assumptions and misapplication of maturity criteria on size-at-maturity estimates for American lobster. Trans Am Fish Soc 134:1075-1090

Waddy SL, Burridge LE, Hamilton MN, Mercer SM, Aiken DE, Haya K (2002) Emamectin benzoate induces molting in American lobster, Homarus americanus. Can J Fish Aquat Sci 59:1096-1099

Waddy SL, Merritt VA, Hamilton-Gibson MN, Aiken DE, Burridge LE (2007a) Relationship between dose of emamectin benzoate and molting response of ovigerous American lobsters (Homarus americanus). Ecotoxicol Environ Saf 67: 95-99

Waddy SL, Mercer SM, Hamilton-Gibson MN, Aiken DE, Burridge LE (2007b) Feeding response of female American lobsters, Homarus americanus, to SLICE ${ }^{\circledR}$-medicated salmon feed. Aquaculture 269:123-129

- Walters BB (2007) Competing use of marine space in a modernizing fishery: salmon farming meets lobster fishing in the Bay of Fundy. Can Geogr 51:139-159

Willis KJ, Ling N (2003) The toxicity of emamectin benzoate, an aquaculture pesticide, to planktonic marine copepods. Aquaculture 221:289-297

Zufall F, Franko CH, Hatt H (1989) The insecticide avermectin $B_{1 a}$ activates a chloride channel in crayfish muscle membrane. J Exp Biol 142:191-205

Submitted: May 18, 2009; Accepted: October 4, 2010 Proofs received from author(s): October 27, 2010 